\title{
An assessment of Charter airline benefits for Port Elizabeth and the
}

\section{Eastern Cape}

\author{
Radu Mihailescu \\ (University of Malta, Msida MSD 2080, Malta)
}

\begin{abstract}
Tourism is becoming a vital component for economic development in South Africa. The income generated by the tourism industry is about $6 \%$ of the GDP, which is significant but still falls short of the goal set by the White Paper on Tourism in 2000. In the light of South Africa hosting the 2010 Football World Cup, it is important to identify ways of sustainable tourism development that would continue to increase the benefits to the economy long after the event's over. The main objective of the research was to explore an idea for increasing the level of tourist income generated in the Port Elizabeth (Eastern Cape) area. The idea was researched by means of conducting a cost-benefit analysis of two tourist related projects. These projects would introduce Charter airline services between Europe and Port Elizabeth. A second objective was to identify constraints on the project or market failures which would prevent their implementation. The economic theory behind the operation of an airline showed that lease costs and aeroplane operating costs are the two most important factors determine Charter airline's profitability. In order to offset these costs, airlines must achieve high passenger load factors. Charter airlines have the advantage over scheduled airlines, in that they will only fly if a minimum level of people has pre-booked seats. Two aeroplanes were chosen for comparison purpose: an Airbus A 340-300 and a Boeing 767-300ER. The private benefits calculated were based on load factors between 80 and 95 percent for ticket prices of USD 667 and USD 773. In addition, to private costs and benefits, social benefits were also estimated in the form of additional secondary revenue generated. With the introduction of net social benefits, both projects become profitable. A 50 percent substitution of revenue generated by the Charter tourists reduces the profits for the both projects drastically. A project based on a Boeing 767-300ER is the most efficient project as it has the highest NPV and BCR values. A reduction in the lease cost of the Airbus 340-300 could make projects based on it more competitive. A few constraints on the establishment of a Charter airline operator based in Port Elizabeth are: the lack of adequate runway for the landing of the long-haul carriers and the need of a larger liberalisation of the aviation policy by eliminating protectionism. The cost benefit analysis undertaken in this research does not take into account social costs and benefits to the economy of establishing a Charter airline based in Port Elizabeth, such as an employment, infrastructure development and poverty alleviation. Nevertheless the analysis does suggest that there are strong private and social benefits warranting the establishment of an airline business between Europe and Port Elizabeth. The economic benefits of the tourism industry and its link to airline travel are outlined in section 3. It is shown that the growth of the airline industry is a major component and contributor to tourism growth.
\end{abstract}

Key words: cost-benefit analysis; private cost/benefits; Airbus A 340-300; Boeing 767-300ER; substitution effect, load factor, discount rate.

Radu Mihailescu, MComm, senior lecturer of University of Malta; research fields: travel and tourism economics. 


\section{Introduction}

For many countries, the travel and tourism industry is the primary generator of revenues, employment, private sector growth and infrastructure development. In common with the worldwide pattern, tourism in South Africa is also becoming an important generator of revenue in the economy. South African tourism grew by almost $14 \%$ in 2006, three times of the global tourism growth rate of $4.5 \%$ for the same period (South African Tourism, 2007). In 2005, the tourism industry contributed to about 3\% of GDP, and at present it seriously challenges the mining industry as one of the major contributors to the country's economic growth (Ntuli, 2009).

The tourism development study undertaken between 2004 and 2006, consider Eastern Cape and particularly Port Elizabeth as regions in need of sustainable tourism development due to the high unemployment rate and the requirement for long-term economic growth.

Eastern Cape is the second largest province of South Africa. It offers a large variety of tourism products such as: a large number of malaria free game reserves, 800 kilometres subtropical coastline, South Africa's only ski resort at Tiffindell and South Africa's largest biodiversity. Port Elizabeth is the biggest city in the Eastern Cape situated on the South Eastern Coast of South Africa about 750 kilometres from Cape Town. It is a city that offers a diverse selection of attractions, scenic nature trails, historic heritage, magnificent wildlife, cultural experiences, countless water sport activities and 40 kilometres beautiful coastline and beaches (see Fig. 1).

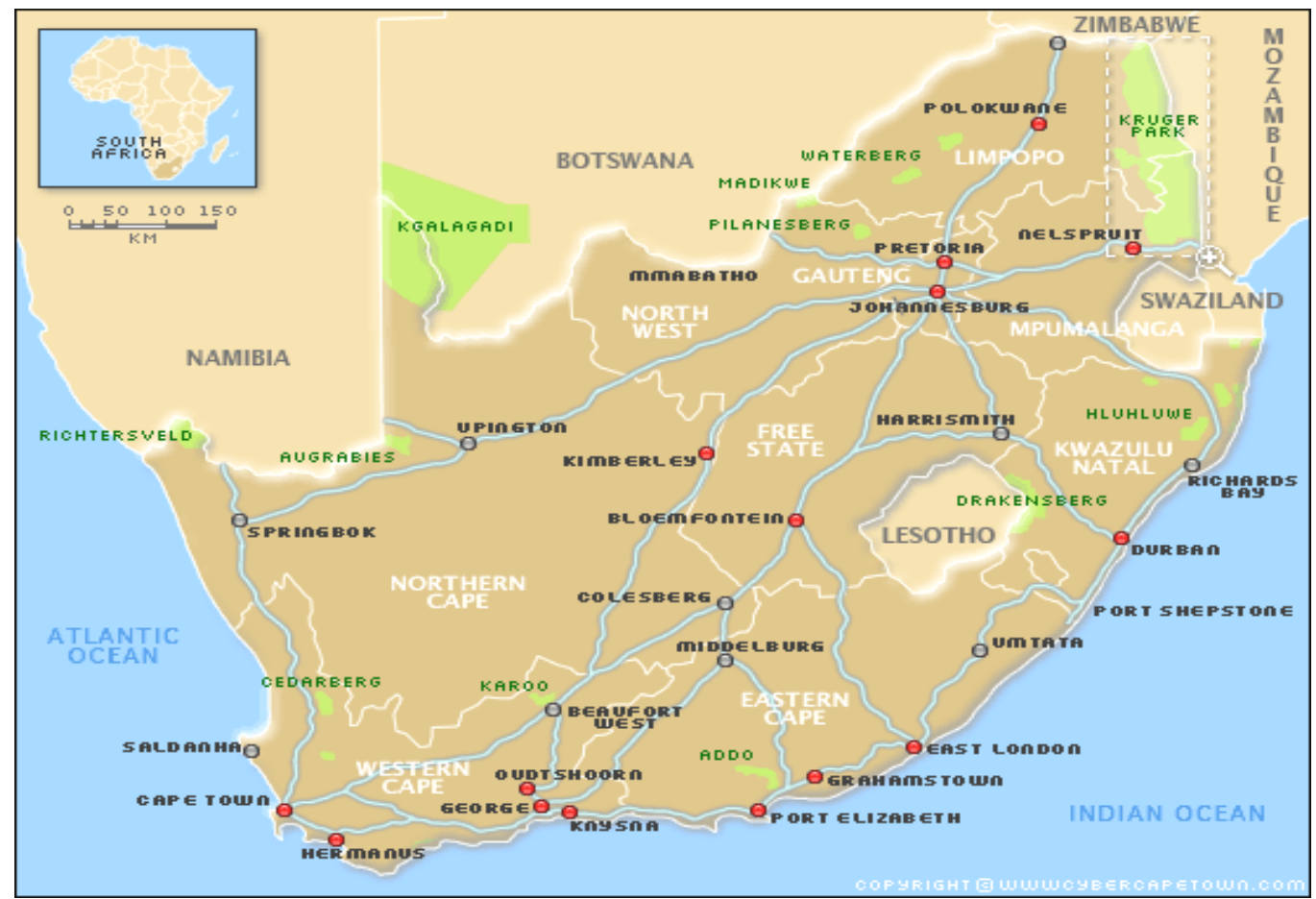

Fig. 1 Map of South Africa

Data source: http://cybercapetown.com/Maps/images/sa.gif.

Despite this variety in tourism products, the Eastern Cape is one of the regions in South Africa that has been least successful in attracting tourists. Of the tourists that arrive at the Johannesburg International Airport or Cape Town International Airport only a small proportion reach the Eastern Cape (Horwath Tourism \& Leisure Consulting, 2000). One of the reasons for this unfortunate state of affairs is the additional cost of purchasing a 
plane ticket from these ports of entry to Port Elizabeth or East London (the second largest city in this region). It was against such background that this study was initiated, with the focus of attention being an investigation on establishing a Charter airline based in Port Elizabeth, Eastern Cape (P.E.).

There are two main objectives of this research study. The first is to explore the economic viability of flying a Charter airline between Port Elizabeth and Northern Europe by analysing the costs and benefits associated with return flying trips for two types of aeroplanes (Airbus A340-300 and Boeing 767-300ER); The second objective is to identify further benefits to the economy by looking at the increase of income generated in the local economy due to the increase in the number of tourists.

The approach being taken in order to achieve the first goal is the analysis of the costs and benefits associated with flying the aeroplanes between Port Elizabeth and selected European destinations. The selected country destinations are UK, France, Germany and the Netherlands. Due to the relative proximity of these destinations the costs of a Charter airline business from them to South Africa is virtually identical. The project proposes 12 non-stop return trips per year. To be viable, Charter airlines need to operate at close to capacity load factors, i.e., at load factors between 85 and 90 percent.

The main method of analysis used in this dissertation is cost-benefit analysis (CBA). The CBA will compare the costs and benefits of flying two aeroplanes, namely the Boeing 767-300 ER and Airbus A340-300, between Port Elizabeth and selected destinations in Northern Europe. In addition trends and patterns in tourism data are examined.

The costs of the Charter airline project include lease costs, actual costs of flying the aeroplanes, maintenance costs and crew costs. The main benefits considered take the form of profits realised by the Charter company. Tourism benefits were calculated by using the income multiplier of additional tourism to Eastern Cape. External benefits that were not estimated include increases in employment and other beneficiaries from the construction of tourism infrastructure. The additional income to the economy is determined solely with reference to the accommodation industry.

The research tested the viability of establishing a Charter airline business based in Port Elizabeth by applying cost-benefit analysis (CBA) to such a business. The CBA is conducted for two different makes of aeroplanes, namely the Airbus A 340-300 and the Boeing 767-300 ER. Selected Charter airline project options are defined with respect to these aeroplanes. The CBA includes the additional costs and benefits associated with the accommodation industry in Port Elizabeth. Benefits and costs are expressed at 2003 price levels, i.e., the base year is 2003. The project period was set at 5 years.

The discount rate serves as a measure of the opportunity cost rate over time of the funds used to finance the project. The source of the funds needed to finance this Charter would most likely be South African financial intermediaries. The real rate of interest these institutions would charge varies considerably over time. One estimate of the rate is 10.1 percent by du Preez (2003, p.181) of 10.1 percent. The other estimation is that of Hosking, et al (2002) of 10.1 percent. The figure constituted a weighed discount rate, using the three sources of funds available for the Working for Water Programme from 1996 to 2000. These estimates are similar to the standard discount rate of 10 percent recommended by the World Bank for developing countries projects (World Bank Organisation, 2002).

Three decision-making criteria are typically used to determine the feasibility of a project: net present value (NPV), the benefit cost ratio (BCR) and the internal rate of return (IRR) (du Plessis, 2003). For the two projects identified above, the net present value (NPV), internal rate of return (IRR) and the discounted benefit-cost ratio 
(BCR) of the initial investment were calculated over a period of five years. The period of five years was chosen on the basis of the recommendations by the European Organisation for the Safety of Air Navigation (1996). A longer time frame yields less accurate results due to the big variations in fuel price as well as costs of equipment heavily influenced by foreign exchange rate of the rand (Currency of South African).

\section{The projects}

The various projects compared in this research were: (1) a Charter airline service between Europe and P.E., based out of P.E., using a leased Boeing 767-300ER, and (2) a Charter airline service between Europe and P.E., based out of P.E., using a leased Airbus 340-300. The reasons for choosing these two aeroplanes were:

- Their ability of flying over long distances without stopovers;

- Their fuel is efficient when compared with larger aeroplanes;

- Larger degree of flexibility regarding the increase of number of available passenger seats;

- The large number of Boeing 767-300ER and Airbus A340-300 aeroplanes which are available for leasing on the market.

\subsection{The routes}

The reason for selecting a route between P.E. and Northern Europe is that countries in the North of Europe are traditionally the main sources of tourists to South Africa. The reason for selecting P.E. rather than East London as the gateway into the Eastern Cape was because it is already currently the main airport gateway into the Eastern Cape.

Of the total number of foreign tourists visiting South Africa in 2003, 7.8 percent visited the Eastern Cape (Centre for Tourism Studies, 2003). The majority of these tourists (78.3 percent) were European residents (Eastern Cape Tourism, 2003). Table 1 indicates the yearly tourism growth from 2002 to 2006.

Table 1 Foreign tourism growth for Eastern Cape

\begin{tabular}{|c|c|c|c|c|c|}
\hline Year & 2002 & 2003 & 2004 & 2005 & 2006 \\
\hline Foreign tourist arrivals & 616,828 & 646,800 & 679,140 & 713,097 & 748,752 \\
\hline Expenditure foreign tourism & $\$ 38 \mathrm{mil}$. & $\$ 37 \mathrm{mil}$. & $\$ 43 \mathrm{mil}$. & $\$ 55 \mathrm{mil}$. & \$58 mil. \\
\hline Average length of stay (days) & 3 & 3 & 3 & 4 & 4 \\
\hline
\end{tabular}

Data source: Eastern Cape Tourism (2007).

Table 1 indicates that while a steady growth of the foreign tourism arrivals is experienced, the average length of stay is short when compared with other provinces in South Africa. It appears that most of the foreign tourists visiting the province are mainly transitory on the way to visit the Western Cape and so they only stay in it for a short period. Tourists brought in by the proposed Charter project could improve the situation, as research shows that tourists travelling on Charter packages tend to spend between 7 to 14 days in the same area within a 300 kilometres radius (Gold, 2001).

As the current main flows of tourists are between Northern European countries and South Africa, it made sense that the proposed Charter tour projects being considered should fly between Port Elizabeth and selected Northern European airports. The most appropriate destinations selected are those shown in Fig. 2.

Due to the operation flexibility associated with Charter airlines, the routes selected can be changed for every flight in order to achieve maximum (desired) load factor. The flight can land in any one of the locations chosen above if the demand is high enough to satisfy the load factors required for a viable Charter flight. The flight costs 
from Port Elizabeth to any of these airports are similar. The average distance that the plane would have to travel for a one-way trip is 9,300 kilometers, while a return flight a distance of 18,600 kilometers. To make the flight become profitable, load factors need to be achieved in the region of 85 to 90 percent.

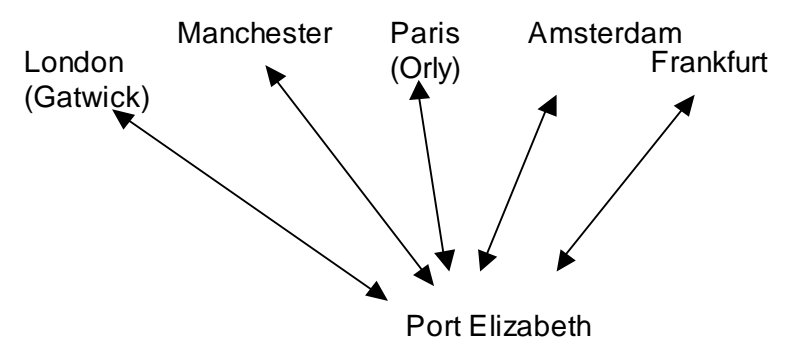

Fig. 2 Typical route followed by a proposed Charter airline

\section{Methodology}

\subsection{Methodology employed in calculating costs and benefits}

The most common method of comparing the cost effectiveness of commercial aircraft is the direct operating cost (D.O.C.) method (Shevell, http://adg.stanford.edu/aa241). This method is used in calculating the private costs of operating the two commercial aeroplanes chosen for the CBA. Additional costs associated with the establishment and operations of a Charter airline are also explored.

The operating costs for both projects, an Airbus A340-300 and a Boeing 767-300 ER for Charter service, are estimated. In addition, to the operating costs, the leasing costs for each aeroplane are also included. The profits for each aeroplane are calculated for selected airfares and load factors. The load factor percentage is used to estimate the number of passengers needed to cover the costs for each flight. The social benefits, in form of additional spending by the tourists, are also estimated for each project. In order to assess the feasibility of the project, its benefit stream must be weighted against its cost stream over the project's lifetime (du Plessis, 2003). The initial investment required for each project was calculated based on the average deposit requirement when leasing the planes at \$ 760,595 for the Boeing 767-300 ER project and at \$765,460 for the Airbus A340-300 project.

The fuel cost may be calculated using the formula shown by Kostiuk (2003):

Fuel costs $=$ ASK $\times\{($ fuel price/gallon $) /[($ ASK/block hours $) /($ gallons/block hours $)]\}$,

where ASK represents the available seat kilometre. Block hours represents the distance flown measured in the amount of time (hours) the aeroplane spends in the air. Maintenance costs constitute about 10 percent of a flight's operating costs. The maintenance costs are derived as follows (Kostiuk, 2003):

Maintenance costs $=$ ASK $\times[(($ maintenance labour + maintenance material $) /$ block hour $) /($ ASK/block hour $)]$

Flight personnel costs include the salaries of the cockpit crew and the flight attendants. The number of seats per attendant was taken to be 50 requiring an average of seven attendants per plane. The flight personnel labour rate is an average of the industry rate for both cabin and cockpit crew (Solomon, 2004):

Flight personnel costs $=$ ASK $\times\{[($ cockpit crew + cabin crew $) /$ block hour $] /($ ASK/block hour $)]\}$

Part of the ownership cost includes the cost of insurance and the cost of acquisition/leasing of the airplane. The lease considered in the research was a dry lease, excluding the costs of aircraft maintenance, crew and insurance costs. Hull insurance costs were assumed to be 2 percent of the ownership costs.

Other relevant charges are the landing charges, navigation charges and airport terminal rent charges. Landing and airport terminal charges are highly variable and differ widely between airports. All the indirect costs are 
calculated via the formula:

$$
\text { Indirect costs }=\mathrm{ASK} \times \text { (indirect costs/ASK) }
$$

The non-aircraft insurance can be quite volatile. However, its impact on the ownership costs is negligible. It constitutes a small percentage of the airline cost index, about 0.2 percent (Air Transport Association, 2003).

\subsection{CBA decision criteria}

Three decision-making criteria are typically used to determine the feasibility of a project: net present value (NPV), the benefit cost ratio (BCR) and the internal rate of return (IRR) (du Plessis, 2003). For the two projects identified above the net present value (NPV), internal rate of return (IRR) and the discounted benefit-cost ratio (BCR) of the initial investment were calculated over a period of five years. The period of five years was chosen on the basis of the recommendations by the European Organisation for the Safety of Air Navigation (1996). A longer time frame yields less accurate results due to the big variations in fuel price as well as costs of equipment heavily influenced by foreign exchange rate of the rand. In order to compare costs incurred and benefits accrued in different years, they must be discounted to a common base year value. The discount rate reflects the changing value of benefits or costs over time.

\subsubsection{Discussion criteria with annual discounting periods}

The NPV is the discounted sum of all the net benefits over the economic project life. It can be described by the following formula:

$$
N P V=\sum_{j=1}^{n} b_{j} /(1+i)^{j}-\sum_{j=1}^{n} c_{j} /(1+i)^{j}
$$

where $b_{j}$ is the projected benefits, $c_{j}$ is the costs, $i$ is the social discount rate and $j$ is the number of year in which the cost or benefit occurs after the commencement of the project. A project is only deemed to be worthwhile if the NPV exceeds zero. A lower NPV means that the present value of the costs exceeds the present value of the benefits (Vanhove, 2005).

The IRR is an interest rate that discounts the cash flows in such a way that the net present value is zero (Young, 1993).

$$
\sum_{j=1}^{n} b_{j} /(1+i)^{j}-\sum_{j=1}^{n} c_{j} /(1+i)^{j}=0
$$

If the IRR is larger than the social discount rate, a project is deemed to be socially worthwhile to be proceed.

The BCR is defined as the ratio of the present value of the benefits to be the present value of the costs and is calculated using the equation:

$$
B C R=\left[\sum_{j=1}^{n} b_{j} /(1+i)^{j}\right] /\left[\sum_{j=1}^{n} c_{j} /(1+i)^{j}\right]
$$

A project will only be considered if the benefit-cost ratio is greater than 1 (Conningarth Economists, 2002).

Ideally, a sensitivity analysis should be undertaken in order to examine the sensitivity of the project's economic performance to the variation of individual parameters (such as per-seat tariff and load factor in the case under consideration). The purpose of the sensitivity analysis is to identify the most critical issues and the degree of their impact (Eurocontrol, 1996).

3.2.2 Decision criteria with monthly discounting period

The Charter projects' cost and benefit flows were not analysed on a yearly basis but on a monthly basis. To 
find the interest rate per month, the equation for $i$ is:

$$
\mathrm{i}_{12}=(\mathrm{r}+1)^{1 / 12}-1
$$

where $r$ is the annual rate (Young, 1993). This value of the monthly interest rate $\left(i_{12}\right)$ was used in equation (1), equation (2) and equation (3).

\section{Operating costs of the two projects}

Table 2 compares the costs of the two projects: the Boeing 767 300-ER Charter project and the Airbus A 340-300 Charter project. The prices and availability of the aircrafts reflect the 2003 market conditions.

Table 2 Comparison of operating costs between Boeing 767-300ER and Airbus A 340-300

\begin{tabular}{|c|c|c|}
\hline Aircraft type & A340-300 & 767-300ER \\
\hline Manufacturer & Airbus Industrie & Boeing \\
\hline Engine & CF M56-5C4 & GE CF6-80C2B7F \\
\hline Seats & 335 & 351 \\
\hline \multicolumn{3}{|l|}{ Operating cost per trip (USD) } \\
\hline Trip Distance (nautical miles) & 5000 & 5000 \\
\hline Number of trips per year ${ }^{1}$ & 24 & 24 \\
\hline Ownership per trip (USD) & $35,567.74$ & $33,150.00$ \\
\hline Variable cost per Trip (USD) & $48,280.21$ & $49,946.42$ \\
\hline Fuel & $17,795.02$ & $19,650.86$ \\
\hline Crew-Flightdeck & $5,434.78$ & $5,434.78$ \\
\hline Crew-Cabin & $3,913.04$ & $3,913.04$ \\
\hline Navigation charges & $16,885.50$ & $16,832.89$ \\
\hline Maintenance per flight hour & $4,251.87$ & $4,114.85$ \\
\hline Fixed cost per trip (USD) & $18,721.86$ & $18,769.01$ \\
\hline Landing charges & $4,702.50$ & $4,673.24$ \\
\hline Noise surcharge & 0.00 & 0.00 \\
\hline Groundhandling & $3,245.00$ & $3,355.00$ \\
\hline Maintenance per cycle & 679.59 & 646.00 \\
\hline Utilities \& Office supplies & $10,094.77$ & $10,094.77$ \\
\hline Total operating cost per trip (USD) & $102,569.81$ & $101,865.43$ \\
\hline Total operating cost per year (USD) & $2,461,675.44$ & $2,444,770.32$ \\
\hline Cost per seat-trip (USD) & $2,143.24$ & $2,031.50$ \\
\hline
\end{tabular}

\subsection{Benefits of the projects}

The benefits of the two projects depend on the ticket prices set by the Charter package operator and the revenues accrued by the local/domestic accommodation industry.

\subsection{Tariffs charged by the Charter airlines}

A 14-day holiday package to South Africa (Cape Town) from the UK (Manchester) was priced at \$1,118 in 2003 including a ticket price cost of \$ 667. This service was offered by a specialist operator, CT2, who used a leased Boeing 767-300ER (de Souza, 2003).

By comparison, Table 3 shows the different tariffs currently charged by major airlines on the selected routes

\footnotetext{
124 trips per year represents one return flight per month.
} 
in 2003.

On average, the scheduled airlines will charge higher ticket prices than Charter airlines on similar routes (Makings, 2004).

Two airline ticket prices were considered for the Charter package projects under consideration: one of \$ 667 representing a 23 percent discount and one of \$ 733 representing a 15 percent discount on the average cheapest fare charged by scheduled airlines (see Table 3). From a tourist's perspective, the final price paid for the holiday will include the additional price of accommodation, catering and local transportation, as well as the cost of the air ticket.

Table 3 Cheapest airfares between Port Elizabeth and selected European countries

\begin{tabular}{|c|c|}
\hline Country & Average fare (USD) \\
\hline UK & 910 \\
\hline France & 1,065 \\
\hline Germany & 928 \\
\hline The Netherlands & 929 \\
\hline
\end{tabular}

Data sources: Flight Centre, Travelocity.com, South African Airways (2004).

The competitiveness of the inclusive tour package offered by the Charter operator depends on the discount obtained for the other tourist products that form the whole Charter package, as well as cost reductions in the day-to-day operation of the airline. A higher frequency of flights, for example an average of once a week, drives down the per flight costs of maintaining and operating the aeroplane and, as a result, lower fares can be charged or higher profits be made.

\section{The cost-benefit project evaluation}

\subsection{Economic ratios for private costs and benefits}

The private costs and benefits are considered below for each project. Table 4 shows the results for the NPV, IRR and BCR separately for the two airplanes at load factors of between 85 percent in low season and 90 percent in high season and a return ticket price of them.

Table 4 Summary of CBA results at a proposed tariff of \$ 667 per seat for 85 and 90 percent load factors

\begin{tabular}{|c|c|c|}
\hline & Boeing 767-300ER & Airbus A 340-300 \\
\hline NPV (USD) & 156,005 & $-263,682$ \\
\hline IRR (\%) & 27.14 & -29.61 \\
\hline BCR & 1.02 & 0.97 \\
\hline
\end{tabular}

Table 4 shows that both the NPV and IRR results for the Airbus A340-300 project are negative. In the case of Boeing 767-300ER, the NPV and IRR results are positive, and the BCR is 1.02 showing that the project is viable. The results for the Airbus A340-300 could change only if the aeroplane is purchased at a lower leasing rate.

Table 5 shows the NPV, IRR and BCR results for the two aeroplanes at 85 and 90 percent load factors and ticket price of $\$ 733$.

The NPV, IRR and BCR results at a tariff of $\$ 733$ show that both projects are viable for load factors of 85 percent and higher. An increase of R 67 to the tariff charged has increased the NPV value for the Airbus A340-300 from a loss of $\$ 263,682$ to a positive $\$ 853,919$. Table 5 shows that higher ticket price reduces the high load 
factor requirements needed to make a profit. The Charter project using the Boeing 767-300ER aircraft is clearly the better investment than one using the Airbus 340-300, irrespective of load factors and tariffs.

At a tariff of \$ 667, the NPV and IRR results for the Boeing project are both positive while the results for the Airbus project are negative; For a tariff of $\$ 733$, the NPV of a Charter airline using a Boeing 767-300ER is substantially higher than that of the Airbus 340-300. The BCR analysis at ticket prices of \$ 667 and \$ 733 is consistent with the NPV findings. At an airfare of \$ 667, the project including the Airbus aircraft yields \$ 0.97's worth of benefits for every dollar spent, while the project with the Boeing 767-300ER yields \$ 1.02's worth of benefits for every dollar spent. For a return ticket price of $\$ 733$, the BCR results are even more impressive (see Table 5).

Table 5 Summary of CBA results at a proposed tariff of \$ 733 per seat for 85 and 90 percent load factors

\begin{tabular}{|c|c|c|}
\hline & Boeing 767-300ER & Airbus A 340-300 \\
\hline NPV (USD) & $1,180,123$ & 853,919 \\
\hline IRR (\%) & 277.32 & 143.68 \\
\hline BCR & 1.12 & 1.09 \\
\hline
\end{tabular}

Based on the results shown above, the conclusion drawn is that the Boeing 767-300ER is a better project option than the Airbus 340-300. The reason for the Boeing 767's better performance with regard to the NPV, IRR and CBR can be attributed to several factors. The main one is that ownership/lease costs are substantially lower than those of the Airbus 340-300. A second factor that contributes to the better economic performance is the larger seat capacity of the Boeing 767-300ER. Assuming that the airline achieves high load factors, the capacity of the aeroplane is of a vital importance in terms of the revenue generation-The Boeing has 16 more seats than the Airbus.

\subsection{Incorporating social benefits into the discussion criteria}

A more completed project appraisal requires the incorporation of the net social benefit of the additional tourism income benefits to the accommodation sector into the decision criteria. Table 6 calculates the gross income benefits without substitution effect and depreciation costs.

Table 6 CBA results incorporating gross tourism income injection benefits

\begin{tabular}{|c|c|c|}
\hline & Boeing 767-300ER & Airbus A 340-300 \\
\hline Fare (USD) & 667 & 667 \\
\hline NPV (USD) & $16,638,575$ & 2.54 \\
\hline BCR (USD) & 2.67 & 733 \\
\hline Fare (USD) & 733 & $16,615,744$ \\
\hline NPV (USD) & $17,662,693$ & 2.66 \\
\hline BCR (USD) & 2.77 & 142 \\
\hline
\end{tabular}

Table 7 shows the tourism income benefits for the two projects after provision is made for a 50 percent reduction due to substitution effects and depreciation costs.

The appeal of the Charter airline projects increases dramatically when the net tourism income injection benefit is incorporated in the calculations. The Airbus project also becomes desirable at a fare of $\$ 633$ when the net income benefits are attached to its revenues. 
Table 7 CBA results incorporating net tourism income injection benefits

\begin{tabular}{|c|c|c|}
\hline & Boeing 767-300ER & Airbus A 340-300 \\
\hline Fare (USD) & 667 & 667 \\
\hline NPV (USD) & $6,337,803$ & $5,546,726$ \\
\hline BCR (USD) & 1.64 & 1.56 \\
\hline Fare (USD) & 733 & 733 \\
\hline NPV (USD) & $7,361,922$ & $6,764,326$ \\
\hline BCR (USD) & 1.74 & 1.68 \\
\hline
\end{tabular}

\section{Market failures and constraints identified}

The results, for most of the scenarios described, suggest that the establishment of a long haul Charter airline based in the Nelson Mandela Metropolitan Area is an economically attractive project. The benefits are not limited only to the airline itself, but spill over into the economy of the region as a whole. Based on these findings, a question must be asked: Why such a Charter operation has yet to be established? From an economic perspective, the lack of a current operating Charter business could be attributed to a number of market failures and constraints.

(1) The main constraint to the operation of a long haul Charter airline, based in Port Elizabeth, is the inadequate length of the airport runway and (until recently) the lack of a proper customs section. The latter limitation was addressed in 2003 when the Port Elizabeth airport received international status after the completion of its \$ 4 million upgrade. However, despite the development of its terminals, the airport runway does not have enough length to accommodate the landing of large long haul aeroplanes. Currently, it is impossible for a fully loaded Boeing 767-300 ER or Airbus A340-300 to land at the Port Elizabeth airport.

(2) Although South Africa's aviation policy has undergone some degree of liberalisation, South African Airways remains largely under its protection. An example of this protection is the current bilateral agreement with the UK, which serves to restrict the demand for South African tourism products (Horwath Consulting, 2000). The effect of this agreement is that, despite the United Kingdom being one of the world's main suppliers of tourists, only three percent of its long-haul passengers visit South Africa. One response to the perceived under-service supply situation was the decision of Nationwide Airlines to enter the long-haul market by introducing three flights per week between Gatwick and Johannesburg. According to de Sousa (2003, p.2), the company expected load-factors on its flights in excess of 70 percent.

(3) Current law states that a local based Charter airlines can be closed down if there are objections to its operations from scheduled airlines. This law discourages locally based Charter airlines from entering the market. However, the current legislation is under review, and further liberalisation of the aviation policy is expected in South Africa.

(4) Until recently, very little data on tourism numbers to the Eastern Cape existed. As a result, there was no clear picture on the growth of the tourism industry in the region. Similarly, there was little or no data regarding the contribution of the tourism and leisure industry to the region's GDP. Without this information, an accurate estimate of the full impact of tourism on the GDP cannot be made. As a result, investors/stakeholders are reluctant to enter commitments to offer Charter packages.

Without addressing these obstacles, projects concerning to introduce a locally based Charter airline services are unlikely to be implemented. The single most important constraint that needs to be remedied would appear to be the lack of adequate length runway for landing of long haul aeroplanes. The costs of extending the runway 
were not considered as a component of the Charter projects-These costs were implicitly included under charges levied by ACSA on the Charter operator.

\section{Conclusions}

The demand for and supply of air travel services to foreign tourists to South Africa have often fallen out of line. Under these circumstances, Charter airline projects can play an invaluable role, for example that of relieving constraints on the accessibility of foreign tourists who are willing to visit South Africa and the Eastern Cape in particular. One of the advantages of Charter airlines is the fact that they are better able to respond to large fluctuations in operating costs due to their operational flexibility.

A CBA model of the two proposed Charter projects, one using the Airbus A 340-300 and the other using a Boeing 767-300ER, showed the requirements and margins under which such an airline business would operate.

A private CBA analysis showed that for a ticket price of $\$ 667$, a Charter project using the Boeing 767-300ER aeroplane is efficient at load factors of between 85 and 90 percent while a Charter project using the Airbus 340-300 project is not. For the higher tariff of $\$ 766$, both projects are viable at load factors of 85 percent or higher.

The inclusion of social benefits greatly improves the appeal of the projects. The additional benefit considered was the income derived by the local accommodation industry. When this is included, both aeroplanes have positive NPV values and BCR values in excess of one. If a net secondary income injection benefit is provided the Airbus and the Boeing Charter projects are both viable. The greater the secondary impact the more desirable the two projects become.

The Boeing 767-300ER Charter airline project yields the higher NPV and BCR values than the Airbus 340-300 project. The main variable that makes the Airbus Charter project less efficient is the higher lease cost relative to the Boeing's. Securing a lower lease price would improve the viability of the Airbus 340-300 Charter project.

\section{Recommendations}

If the Charter projects proposed and investigated in the dissertation are to be taken forward a number of issues warrant further investigation:

(1) A Charter airline service introduced between Europe and P.E. will not only yield benefits to the accommodation industry, but also to other sectors related to the tourism industry, e.g., transport providers, catering industry.

(2) Other potential constraints to tourism development in the region need to be taken into account, such as: prices of tourism products, crime and tourism infrastructure development.

(3) The implications of the project on income generation, employment creation and poverty alleviation in the Eastern Cape need to take account of how much time the tourists will spend in the province and exactly what are the areas most likely to be visited.

(4) Although Charter aeroplanes sacrifice cargo space in favour of increased passenger capacity, further study could identify how low load factors can be subsidised by using the revenues from cargo transportation.

(5) The impact of the tourism industry needs to be accurately measured in order to gauge its contribution to the economic growth in the Eastern Cape relative to the growth in other sectors. Part of measuring this impact is 
re-calculating the tourist spending income multiplier for the Eastern Cape.

\section{References:}

Air Transport Association. (2003, April). Airline handbook chapter 4: Airline economics. Retrieved from http://www.airtransport.org/public/publications/.

Centre for Tourism Studies. (2003). A tourism industry intelligence service. University of Port Elizabeth.

Conningarth Economists. (2002). A manual for cost benefit analysis in South Africa with special reference to water resource development. South Africa Water Research Commission.

De Sousa, M.. (2003, December 3rd). Nationwide makes its UK debut. Retrieved from http://www.travelinfo.co.za.

Du Plessis, L. L.. (2003). An assessment of selected non-water benefits of the working for water programme in the eastern and southern Cape. (Unpublished Masters Dissertation Research: University of Port Elizabeth).

Du Preez, M.. (2003). The economic evaluation of the environmental use of water: Selected case studies in the astern and southern Cape. (Doctoral Dissertation, University of Port Elizabeth)

Eastern Cape Tourism Board. (2003). Eastern Cape Tourism Master Plan. Eastern Cape Development Corporation CD-Rom.

Eastern Cape Tourism Board. (2006). Eastern Cape Tourism Master Plan. Eastern Cape Development Corporation CD-Rom.

European Organisation for the Safety of Air Navigation (EUROCONTROL). (1996). Guidelines for the economic appraisal of EATCHIP projects-The effective use of cost-benefit studies. London: IATA.

Flight Centre. (2004). The captain's travel catalogue. Blackheath: Flight Centre Publishing.

Gold, M. D.. (2001). Starting a viable port Elizabeth based Charter airline and the development of package tours. Power Point Presentation.

Horwath Tourism \& Leisure Consulting. (2000). Protectionist aviation policy restricts economic growth—Aviation policy bulletin. Retrieved from http://www.capeinfo.co.za.

Hosking, S. G., Du Preez M. Campbell E. E., Wooldrige T. H. \& Du Plessis L. L.. (2002). Evaluating the environmental use of water-selected case studies in the eastern and southern Cape. Water Research Commission, Pretoria, Report Number 1045/1/02.

Kostiuk, P. \& Gaier, E.. (2003). ASAC airline cost-benefit model. Logistic Management Institute.

Makings, R.. (2004). Bigger, better, further, faster-cheaper. Sunday Times, 14.

Ntuli, S.. (2009). New tool to measure tourism industry. Retrieved May 12th, 2009, from http://www.southafrica.info/travel/ tsa-120509.htm.

Shevell, R. S.. (2005). Operating costs. Retrieved February 24th, 2005, from http://adg.stanford.edu/aa241/cost.

Solomon, S.. (1994, April). How to start an airline of your own. Retrieved from http://pf.inc.com/magazine.

South African Airways. Fares to Europe. Retrieved from http://www.flysaa.com.

Travelocity.com. (2004). Cheap airfares search. Retrieved February 23rd, 2004, from http://www.trvelocity.com/flights.

Vanhove, N.. (2005). The economics of tourism destinations. Oxford: Elsevier Butterworth-Heinemann.

World Bank Organisation. (2004). Country-at-a glance tables. Retrieved March 28th, 2004, from www.worldbank.org/data.

Young, D. A.. (1993). Financial mathematics: A computational approach. Kenwyn: Juta \& Co., Ltd.

(Edited by Ruby and Chris) 